\title{
Cell Phones- Homes for Microbes!
}

\author{
${ }^{1}$ Dr. Vaishali Rahangdale, ${ }^{2}$ Dr. Sandeep Kokate ${ }^{3}$ Dr.Rajendra Surpam \\ Asst. Prof., Department of Microbiology, Government Medical College, Nagpur \\ Associate Prof., Department of Microbiology, Government Medical College, Nagpur \\ Prof.\& Head, Department of Microbiology, Government Medical College, Nagpur
}

\begin{abstract}
:
Introduction: Mobile phones are in close contact with body serving transportation of bacteria in hospital settings. Further, sharing of mobile phones among health care workers \& non Health care workers distinctly facilitate the spread of potentially pathogenic bacteria to the community.
\end{abstract}

Aims \& Objective: To study the bacterial flora present on cell phones of II \& III MBBS students \& to compare it with that found oncell phones of I MBBS students in terms of antibiotic resistance.

Material \& Methods: Swabs from mobile phones of 100 I st MBBS \& 100 II\& III MBBS students were taken \& processed by standard bacteriological technique. Antibiotic susceptibility done by Kirby-Bauer disc diffusion technique.

Result: Mobile phones of $15 I^{\text {st }}$ MBBS students were contaminated among which $13 \%$ were staphylococcus aureus. Whereas mobile phones of 30 II \& III MBBS students were contaminated. Among these 30 isolates, 9 were staphylococcus aureus of which 2 were MRSA sensitive to vancomycin \& linezolid, 17coagulase negative staphylococcus, 2 pseudomonas aeruginosa, 1E.coli \& lenterobacter species.

Conclusion: To prevent spread of potential pathogens through mobile phones in hospital, hand hygiene ,routine decontamination of mobile phones \& avoiding sharing of phones should be encouraged.

Key Words : Cell phones, Bacterial contamination, Drug resistance, MRSA.

\section{Introduction}

Mobile phones have become part of health professional's equipment and are used extensively for communication in a clinical setting [1]. However, they are seldom cleaned and are often touched during or after examination of patients and even specimens are handled without proper hand washing. These cell phones can harbour various potential pathogens and become exogenous sources of infection for the patients and are also potential health hazard for self and family members [2, 3$]$. Further, sharing of cell phones between HCWs and non-HCWs may directly facilitate the spread of potentially pathogenic bacteria to the community [4].

Nosocomial infections constitute a major problem globally with major social, economic, moral and personal effects that increase morbidity and mortality of hospitalized patients [5]. Different studies in different parts of the world indicated that medical equipment and mobile phones of health care workers are potential sources of nosocomial infections. So, this study focuses on determining the presence \& type of bacteria that contaminate mobile phones of medical students and their antibiotic susceptibility

\section{Aims \& Objective}

1) To study the bacterial flora present on cell phones of I, II \& III MBBS students

2) To study the anti-microbial resistance pattern of bacterial isolates

3) To compare the bacterial flora \& their antimicrobial resistance pattern found on cell phones of I MBBS students with that of II \& III MBBS students.

\section{Material \& Methods}

Mobile swabs of 100 volunteer students of I MBBS \&100 volunteer students of II \& III MBBS were taken. A sterile swab moistened with sterile demineralised water was rotated on the sides and over the keypad of mobile phone. The swabs were immediately inoculated and streaked onto nutrient agar, 5\% sheep blood agar and MacConkey agar (Hi-Media, India) (6).Plates were incubated aerobically at $37^{\circ} \mathrm{C}$ for 24 hours. Isolated organisms were processed \& identified according to standard bacteriological technique (7). Antibiotic susceptibility testing was performed by Kirby-Bauer disk diffusion technique (8). The drugs used were as per theCLSI2013guidelines.MethicillinsensitivityofStaphylococcusaureuswascarried outbycefoxitinndiskdiffusiontest $(9)$. 


\section{Observation}

Table1: Contamination rate of mobile phones of I,II \& III MBBS students

\begin{tabular}{|l|l|}
\hline $\begin{array}{l}\text { Number of contaminated mobile phones } \\
\text { of I MBBS }(\mathrm{n}=\mathbf{1 0 0})(\%)\end{array}$ & $\begin{array}{l}\text { Number of contaminated mobile phones } \\
\text { of II \& III MBBS }(\mathrm{n}=\mathbf{1 0 0})(\%)\end{array}$ \\
\hline $\mathbf{1 5}(\mathbf{1 5})$ & $\mathbf{3 0}()$ \\
\hline
\end{tabular}

A high level of contamination was detected among the II \& III MBBS students as compared to I MBBS students which is significant with $p$ value $=0.01109 \&$ chi sq test $=6.452$.

Table 2: Organisms isolated from mobile phones of I MBBS students( $\mathrm{n}=15)$ :

\begin{tabular}{|l|l|l|}
\hline S.no & Organisms & Number(\%) \\
\hline 1 & $\begin{array}{l}\text { Coagulase } \\
\text { staphylococcus }\end{array}$ & negative \\
\hline 2 & S.aureus & $2(13)$ \\
\hline
\end{tabular}

All the above coagulase negative staphylococcus strains were sensitive to all the tested antibiotics .

All the above staphylococcus aureus strains were resistant to penicillin but sensitive to all other tested drugs.

Table 3 : Organisms isolated from mobile phones of II \& III MBBS students(n=30):

\begin{tabular}{|l|l|l|}
\hline S.no & Organisms & Number (\%) \\
\hline 1 & Coagulase negative staphylococcus & $17(56.66)$ \\
\hline 2 & S.aureus & $9(30)$ \\
\hline 3 & Ps.aeruginosa & $2(6.66)$ \\
\hline 4 & E.coli & $1(3.33)$ \\
\hline 5 & Enterobacter spp. & $1(3.33)$ \\
\hline
\end{tabular}

Table 4: Resistance pattern of staphylococcocci of II \& III MBBS

\begin{tabular}{|c|c|c|c|}
\hline S.no & Drug & $\begin{array}{l}\text { Number of resistant } \\
\text { staphylococcus aureus } \\
(\%)(\mathrm{n}=9)\end{array}$ & $\begin{array}{l}\begin{array}{l}\text { Number of } \\
\text { coagulase }\end{array} \\
\text { staphylococcus }(\%) \begin{array}{r}\text { resistant } \\
\text { negative }\end{array}\end{array}$ \\
\hline 1 & $\mathbf{O x}$ & 2 & 0 \\
\hline 2 & $\mathbf{P}$ & 2 & 0 \\
\hline 3 & Ac & 2 & 0 \\
\hline 4 & $\mathbf{C i}$ & 2 & 0 \\
\hline 5 & $\mathrm{Cn}$ & 2 & 0 \\
\hline 6 & $\mathrm{Cz}$ & 2 & 0 \\
\hline 7 & Cpm & 2 & 0 \\
\hline 8 & $\mathrm{C}$ & 1 & 0 \\
\hline 9 & $\mathbf{R}$ & 1 & 0 \\
\hline 10 & G & 1 & 0 \\
\hline 1 & $\mathbf{E}$ & 2 & 0 \\
\hline 11 & $\mathbf{V a}$ & 0 & 0 \\
\hline 12 & $\mathbf{L z}$ & 0 & 0 \\
\hline 13 & Of & 0 & 0 \\
\hline 14 & Le & 0 & 0 \\
\hline 15 & Pm & 0 & 0 \\
\hline 16 & Co & 1 & 0 \\
\hline
\end{tabular}

E-Erythromycin, Oxacillin, P-Penicillin, Ac-Amoxycillin-clavulanic acid ,Ci - Ceftriaxone, Cn - Cefoxitin,CzCefazoline, Cpm-Cefepime, C-Chloramphenicol, R-Rifampicin,

G- Gentamicin , E-Erythromicin, VaVancomycin, Lz - Linezolid, Of - Ofloxacin, Le - Levofloxacin, Pm- pristinomicin , Co-Co-trimaxazole .

Table 4: Resistance pattern of E.coli \& Enterobacter

\begin{tabular}{|l|l|l|l|}
\hline S.no & Drug & $\begin{array}{l}\text { Number of E.coli } \\
\text { resistant to mentioned } \\
\text { antibiotic(\%) } \\
(\mathbf{n = 1})\end{array}$ & $\begin{array}{l}\text { Number of Enterobacter spp. } \\
\text { resistant to mentioned } \\
\text { antibiotic(\%) } \\
(\mathbf{n}=\mathbf{1})\end{array}$ \\
\hline $\mathbf{1}$ & $\mathrm{A}$ & 0 & 0 \\
\hline $\mathbf{2}$ & $\mathrm{Ac}$ & 0 & 0 \\
\hline $\mathbf{3}$ & $\mathrm{Ce}$ & 0 & 0 \\
\hline $\mathbf{4}$ & $\mathrm{Ci}$ & 0 & 0 \\
\hline $\mathbf{5}$ & $\mathrm{Cfz}$ & 0 & 0 \\
\hline $\mathbf{6}$ & $\mathrm{Cs}$ & 0 & 0 \\
\hline $\mathbf{7}$ & $\mathrm{Nt}$ & 0 & 0 \\
\hline $\mathbf{8}$ & $\mathrm{Tcc}$ & 0 & 0 \\
\hline $\mathbf{9}$ & $\mathrm{Azt}$ & 0 & 0 \\
\hline $\mathbf{1 0}$ & $\mathrm{G}$ & 0 & 0 \\
\hline $\mathbf{1 1}$ & $\mathrm{Ak}$ & 0 & 0 \\
\hline $\mathbf{1 2}$ & $\mathrm{Cf}$ & 0 & 0 \\
\hline
\end{tabular}




\begin{tabular}{|l|l|l|l|}
\hline $\mathbf{1 3}$ & Le & 0 & 0 \\
\hline $\mathbf{1 4}$ & $\mathrm{Pb}$ & 0 & 0 \\
\hline $\mathbf{1 5}$ & Ip & 0 & 0 \\
\hline
\end{tabular}

A-Ampicillin, Ac-Amoxycillin-clavulanic acid ,Ce- Cefotaxime, Ci - Ceftriaxone, Cfz - -Cefazoline, Cs Cefaperazone, , Nt - Natilmicin,Tcc - Ticarcillin,Azt - Aztreonam, cf - ciprofloxacin,le-Levofloxacin, PbPolimymixin B,Ip- Imepenem.

Table 5: Resistance pattern of Psuedomonas spp.

\begin{tabular}{|l|l|l|}
\hline s.no & Drug & $\begin{array}{l}\text { Number } \\
\text { resistant } \\
\text { Psuedomonas } \\
(\mathbf{\%}) \\
(\mathbf{n = 1})\end{array}$ \\
\hline $\mathbf{1}$ & $\mathrm{Cfz}$ & 0 \\
\hline $\mathbf{2}$ & $\mathrm{Ci}$ & 0 \\
\hline $\mathbf{3}$ & $\mathrm{Cpm}$ & 0 \\
\hline $\mathbf{4}$ & $\mathrm{Pc}$ & 0 \\
\hline $\mathbf{5}$ & Tcc & 0 \\
\hline $\mathbf{6}$ & Azt & 0 \\
\hline $\mathbf{7}$ & Pit & 0 \\
\hline $\mathbf{8}$ & Nt & 0 \\
\hline $\mathbf{9}$ & $\mathrm{G}$ & 0 \\
\hline $\mathbf{1 0}$ & Ak & 0 \\
\hline $\mathbf{1 1}$ & Tb & 0 \\
\hline $\mathbf{1 2}$ & Lo & 0 \\
\hline $\mathbf{1 3}$ & Ip & 0 \\
\hline
\end{tabular}

Cfz - Cefazoline, ci - Ceftriaxone,Cpm - Cefepime, Pc - piperacillin,Tcc- Ticarcillin,Azt - Aztreonam, PitPiperacillin-tazobactum, Nt - Natilmicin, G- Gentamicin,Ak - Amikacin, Tb - Tobramycin, Lo -Lomefloxacin, Ip-Imepenem.

\section{Discussion}

Mobile phones due to their personal nature and proximity to sensitive parts of our bodies in usage such as faces, ears, lips and hands of users could become veritable reservoirs of pathogens that could result in infections. Results from this study showed high levels of bacterial contamination of mobile phones used by medical students. Specially a high levels of contamination was seen among the II \& III MBBS students(30\%) as compared to I MBBS students ( $15 \%$ ) which is found significant.

Bacteriological analysis of mobile phones of II \& III MBBS students revealed 30\% contamination with bacteria. These isolated bacteria were : 56.66\% coagulase negative staphylococcus, 30\% staphylococcus aureus, $6.66 \%$ were Pseudomonas aeruginosa \& $3.33 \%$ were E.coli. Thus, total $12(40 \%)$ of the mobile phones were contaminated with bacteria which are well known to be associated with hospital associated infections i.e. Staphylococcus aureus, Pseudomonas aeruginosa \& E.coli which were defined as significant isolates means the organisms commonly associated with nosocomial infections (10).

Again high number of mobile phones of II \& III MBBS students were contaminated with organisms known to cause nosocomial infection as compared to I MBBS students which is also found significant with $\mathrm{p}$ value $=0.04417 \&$ chi sq. Test -4.05 . This difference clearly indicates the exposure of II \& III MBBS students to hospital environment leads to such contamination of mobile phones which is a cause of concern. Comparing our study with other studies, a higher percentage of contamination of mobile phones by these significant isolates was reported by Gashaw et al 2014 reported $99.99 \%$ (11), Datta et al 2009 reported $36 \%$ (12) whereas Karabay $\mathrm{O}$ et al Turkey reported only $9 \%$ contamination (13). Even the organisms isolated from mobile phones of students of II \& III were more resistant to commonly used drugs as compared to I MBBS. This difference could be because of acquiring nosocomial pathogens from the hospital itself during their clinical postings.

In the present study, each mobile phone was contaminated by a single organism.Total $100 \%$ contamination with multiple organisms was reported by Togae et al 2011(14) In the present study, isolation of GNR is less from mobile phones (10\%).Such less isolation of gram negative bacilli from the mobile phones is also reported by Brady et al (10) and Karabay O et al (13).

MRSA detected in present study is $22.22 \%$. various authors reported MRSA from $0 \%$ to higher $\%$ such as Ulger et al 2009 reported $37.7 \%$ ( 15 ). Datta et al reported $18 \%$ (9) Utsan et al 2012 ( 16 ) reported 0 $\%$ MRSA contamination of mobile phones. No multidrug resistant organism was isolated in our study whereas multidrug resistant organisms from mobile phones were reported by Gashaw et al 2014 (11)

\section{Conclusion}

As most of the sampled mobile phones specially of students exposed to hospital environment were highly contaminated with various types of bacteria known to cause nosocomial infection \& also resistant to 
commonly used antibiotics. This suggests the potential of the mobile phone as a fomite, which can result in community-acquired infections with possible public health implications. Periodic cleaning of mobile phones with disinfectants like $70 \%$ isopropyl alcohol or hand cleaning detergents as well as frequent hand-washing should be encouraged as a means of curtailing any potential disease transmission.

\section{References}

[1]. J. Ramesh, A. O. Carter, M. H. Campbell et al., "Use of mobile phones by medical staff at Queen Elizabeth Hospital, Barbados: evidence for both benefit and harm," Journal of Hospital Infection, vol. 70, no. 2, pp. 160-165, 2008

[2]. U. Arora, P. Devi, A. Chadha, and S. Malhotra, "Cellphones a modern stayhouse for bacterial pathogens," JK Science, vol. 11, no. 3, pp. 127-129, 2009.

[3]. H. Kilic, M. Ozaslan, I. D. Karagoz, Y. Zer, and V. Davutoglu, "The microbial colonisation of mobile phone used by healthcare staffs," Pakistan Journal of Biological Sciences, vol. 12, no. 11, pp. 882-884, 2009.

[4]. K. Chawla, C. Mukhopadhayay, B. Gurung, P. Bhate, and I. Bairy, "Bacterial "Cell" phones: do cell phones carry potential pathogens?" Online Journal of Health and Allied Sciences, vol. 8, no. 1, pp. 1-5, 2009.

[5]. S. A. Sallam, M. A. Arafa, A. A. Razek, M. Naga, and M. A. Hamid, "Device-related nosocomial infection in intensive care units of Alexandria University Students Hospital," Eastern Mediterranean Health Journal, vol. 11, no. 1-2, pp. 52-60, 2005.

[6]. Collee JG, Marr W. Specimen collection, culture containers and media In: Collee JG, Fraser AG, Marmion BP, Simmons A (eds) : Mackie \& McCartney Practical Medical Microbiology, $14^{\text {th }}$ ed, NewYork: Churchill -Livingstone, pp 95-112. 1996a

[7]. Collee JG, Miles RS, Watt B.Tests for identification of bacteria In: Collee JG, Fraser AG, Marmion BP, Simmons A (eds) : Mackie \& McCartney Practical Medical Microbiology, $14^{\text {th }}$ ed, NewYork : Churchill -Livingstone, pp $131-50.1996 \mathrm{~b}$

[8]. Bauer AW, Kirby WMM, Sherris JC, Turck M: Antibiotic susceptibility testing by a standardized single disc method. Am J Clin Pathol 45: 493-6,1966

[9]. Clinical and Laboratory Standards Institute, Performance standards for antimicrobial disk susceptibility tests; Approved standard, 2013, vol. 33, No.1, M100-S23.

[10]. Brady RR, Fraser SF, Dunlop MG, Paterson - Brown S, Gibb AP: Bacterial contamination of mobile communication devices in the operative environment. J Hosp Infect $66: 397-8,2007$

[11]. Gashaw M, Abtew D, and Addis Z. Prevalence and Antimicrobial Susceptibility Pattern of Bacteria Isolated from Mobile Phones of Health Care Professionals Working in Gondar Town Health Centers

[12]. ISRNPublicHealth Volume 2014 (2014), Article ID 205074, http://dx.doi.org/10.1155/2014/205074

[13]. 12.P Datta, H Rani, J Chander, V Gupta: Bacterial contamination of mobile phones of health care worker.IJMM 27( 3): 27981,2009

[14]. Karabay O, Kocoglu E, Tahtaci M: The role of mobile phones in the spread of bacteria associated with nosocomial infections. J Infect Developing Countries 1: 72-3,2007

[15]. DN Tagoe, V K Gyande, E O Ansah, Bacterial Contamination of Mobile Phones: When Your Mobile Phone Could Transmit More Than Just a Call__ WebmedCentral MICROBIOLOGY 2(10):WMC002294,2014 Ulger ${ }^{1} \mathbf{F}^{*}$, Saban Esen $\underline{2}$, Ahmet Dilek $\underline{1}$, Keramettin Yanik ${ }^{\underline{3}}$, Murat Gunaydin $\underline{\underline{3}}$ and Hakan Leblebicioglu: Are we aware how contaminated our mobile phones with nosocomial pathogens? Annals of Clinical Microbiology and Antimicrobials 7 doi:10.1186/1476-0711-8-7,2009

[16]. Ustun $\mathrm{C}^{1}$, Cihangiroglu $\mathrm{M}$, Health care workers' mobile phones, a potential cause of microbial cross-contamination between hospitals and community. J Occup Environ Hyg.9(9):538-42. doi: 10.1080/15459624.2012.697419,2009

[17]. P Datta, H Rani, J Chander, V Gupta: Bacterial contamination of mobile phones of health care worker.IJMM 27( 3): 279-81,2009 